\title{
The influence of values in sustainable consumption among millennials
}

\section{Andreas Falke ${ }^{1} \cdot$ Nadine Schröder ${ }^{2} \cdot$ Claudia Hofmann ${ }^{3}$}

Accepted: 10 November 2021 / Published online: 29 November 2021

(c) The Author(s) 2021

\begin{abstract}
Due to climate change and global warming, sustainable consumption-as one possible solution to these challenges - is becoming more and more relevant. One generation that is affected the most by these developments are the millennials. While more and more baby boomers are retiring, millennials are now transitioning from being in training to being full-time employed, which marks a big change in their lives and makes understanding their values and consumption behaviour more important for marketers. The goal of our study is to clarify which values influence the building of attitude of millennials, if this influence differs according to employment status, and how attitude affects purchase intention concerning sustainable goods. Building to the list of values by Kahle (1983), the theory of planned behaviour, and perceived consumer effectiveness, we construct a framework to understand how values and employment status of millennials interact with their purchasing intention. Our results show that, among others, the values, that play a role during purchase intention forming, differ depending on the employment status. We also find that millennials place high importance on being in control when purchasing sustainable goods. Advertising and product managers can use our results to better understand and target the audience of their products as they construct their marketing efforts with the values of the audience in mind. In particular, messages that comply with the notion of being in control should be considered in every communication channel. This way, they may increase the share of sustainable consumers.
\end{abstract}

Keywords Sustainable consumption · List of values · Millennials · Theory of planned behaviour

JEL Classification A13 $\cdot$ C38 $\cdot$ M31

Andreas Falke

andreas.falke@ur.de

Extended author information available on the last page of the article 


\section{Introduction}

Climate change and global warming have been continuously covered in the news during the past years (Nacu-Schmidt et al. 2020). In line with that, various remedies, such as shifting to renewable energies, using more energy efficient products or sustainable consumption, are being discussed. Consumers acknowledge this change, as the market for sustainable products has been growing around the world for more than a decade (Brach et al. 2018). According to the report of the World Commission on Environment and Development of the United Nations of 1987 (WCED 1987), sustainability is the satisfaction of current human needs without impairing the capabilities of future generations to satisfy their needs. Consequently, sustainable consumption is about the simultaneous optimization of environmental, social, and economic consequences that relate to consumption regarding needs of current and future generations (e.g., Brix-Asala et al. 2016). In the food category, the three consequences can be captured by buying organic or locally grown food (environmental), fair trade (social), and reducing buying food in order to reduce waste (economic). Still, depending on which consequence might dominate consumers' values, some customers might buy sustainably grown food for environmental reasons whereas others might be more inclined to the social consequences. This is in line with previous research (e.g., Hwang and Griffiths 2017) who find that - among others - values serve to explain purchase intentions of sustainable products. However, even though sustainable consumption will become more and more important in the future, people are affected differently by the climate change and may therefore show heterogenous effort in buying sustainably. Due to their life expectancy, later born generations such as the millennials or the Generation $\mathrm{Z}$ will be more strongly affected by the climate change compared to previous generations. We contribute to the stream of literature that tries to explain millennials' purchase intention regarding sustainable consumption and extend it by taking the heterogeneity of millennials into account. We are looking at millennials (instead of the Generation $\mathrm{Z}$ ) because a large part (57\% in Germany (VuMa 2018)) has started working and is able to make purchase decisions. In the U.S., millennials are responsible for $\$ 600$ billion in sales (Donnelly and Scaff 2013), which underlines their economic impact.

According to VuMa (2018), everyone who is born between 1981 and 1998 is considered a millennial. For Germany, that means that almost $27 \%$ of the population falls into that category. This generation grew up in a world that has become more and more global and prospering (Parment 2013). Due to this, millennials grew up with different values than previous generations (e.g., Parment 2012). However, as it seems, millennials are a rather heterogeneous than homogenous group. According to previous studies, millennials can be characterized as, e.g., optimistic and goal-oriented (Chen and Choi 2008), traditional and team oriented (Howe and Strauss 2000), and willing to support socially responsible companies (Furlow 2011). In contrast to that, other studies find them to be individualistic or even narcissistic (Twenge and Foster 2010) or at least self-oriented rather than other-oriented (Naderi and van Steenburg 2018). 
In a recent study, Asselmann and Specht (2021) show that getting employed for the first time has significant effects on three of the Big Five personality traits. They conclude that a personality maturation takes place after the start of working life. Therefore, we think that employment might have an impact on millennials' value formation and the way they form purchase intention. Being full-time employed makes people more conscientious, they may perceive to have a new role in society, compared to not (yet) fully employed people. Furthermore, due to their regular wages, they have a higher spending power and can act according to their most important values. Due to that, the transition from not (yet) full-time employed to full-time employed millennials is of particular interest to marketers. This study therefore aims at explaining what drives sustainable consumption. In particular, we are interested in identifying what kind of values play a role in sustainable consumption of vegetables and whether these values unanimously hold for the whole generation or whether transitions in millennials' lives such as beginning a full-time employment have an impact. We outline how marketers can make use of our findings to better understand and target their audience and how being employed makes a difference in the intention forming process.

The following sections will present a comparison to related studies, our theoretical framework, and the resulting hypotheses. Afterwards, we describe the data collection and model evaluation. Next, we present the results of the study, discuss them and derive managerial implications. We conclude with a summary of the study, its main findings, and its limitations.

\section{Comparison to related studies}

In the following, we will briefly discuss previous research on millennials' sustainable consumption. The concept of sustainability is rather diverse, which is also reflected by the various fields in which sustainability is studied (see Table 1). As an example, Ma et al. (2012) analyse purchase intention for fair trade products, Kang et al. (2013) define behaviour intentions for organic cotton as a way to consume sustainably. Other studies look into services, such as the intention regarding car sharing (Hwang and Griffiths 2017) or the adoption of online e-waste platforms (Ramzan et al. 2020). In most of the cases, authors used purchases (e.g., Chan and Lau 2002, Yadav and Pathak 2017) and/or intentions (e.g., Hwang and Griffiths 2017; Stern et al. 1993) as a means to operationalize the construct of sustainable consumption.

In order to explain drivers of sustainable behaviour, most of the studies draw on values (e.g., Hwang and Griffiths 2017, Nordlund and Garvill 2002, Vermeir and Verbeke 2008), the theory of planned behavior (TPB) (e.g., Kang et al. 2013; Ma et al. 2012), and perceived consumer effectiveness (PCE) (e.g., Heo and Muralidharan 2019, Hwang and Griffiths 2017). The majority of prior studies measure values of their respondents by items and factors introduced by Schwartz's (1992) norm-activation theory. For instance, Stern et al. (1995) use them as antecedents of environmental attitude of adult US citizens. Schultz and Zelezny (1999) and Nordlund and Garvill (2002) apply them in their studies on forming attitudes via the new environmental paradigm in the Americas and Sweden, respectively. Finally, Vermeir 


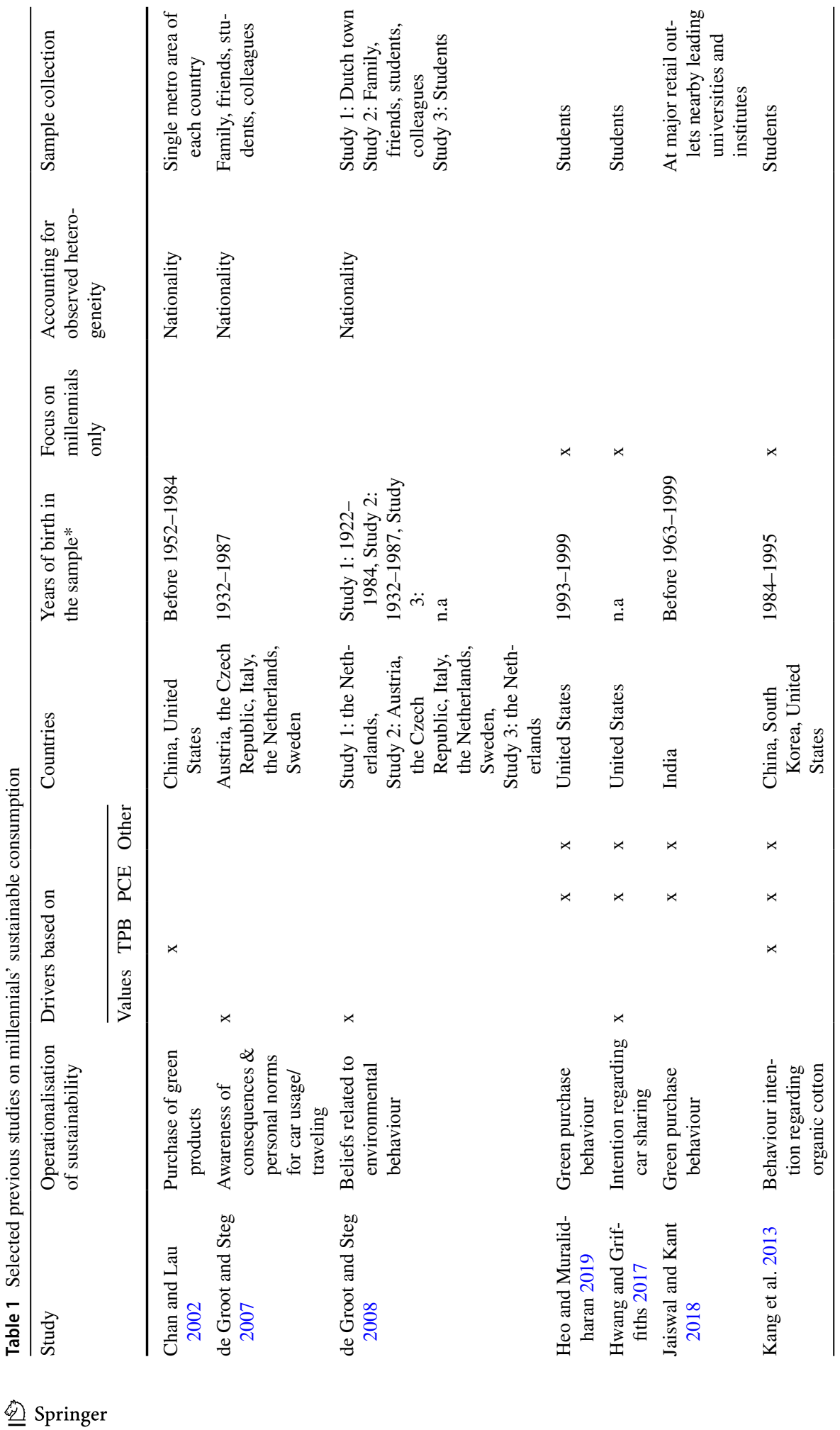




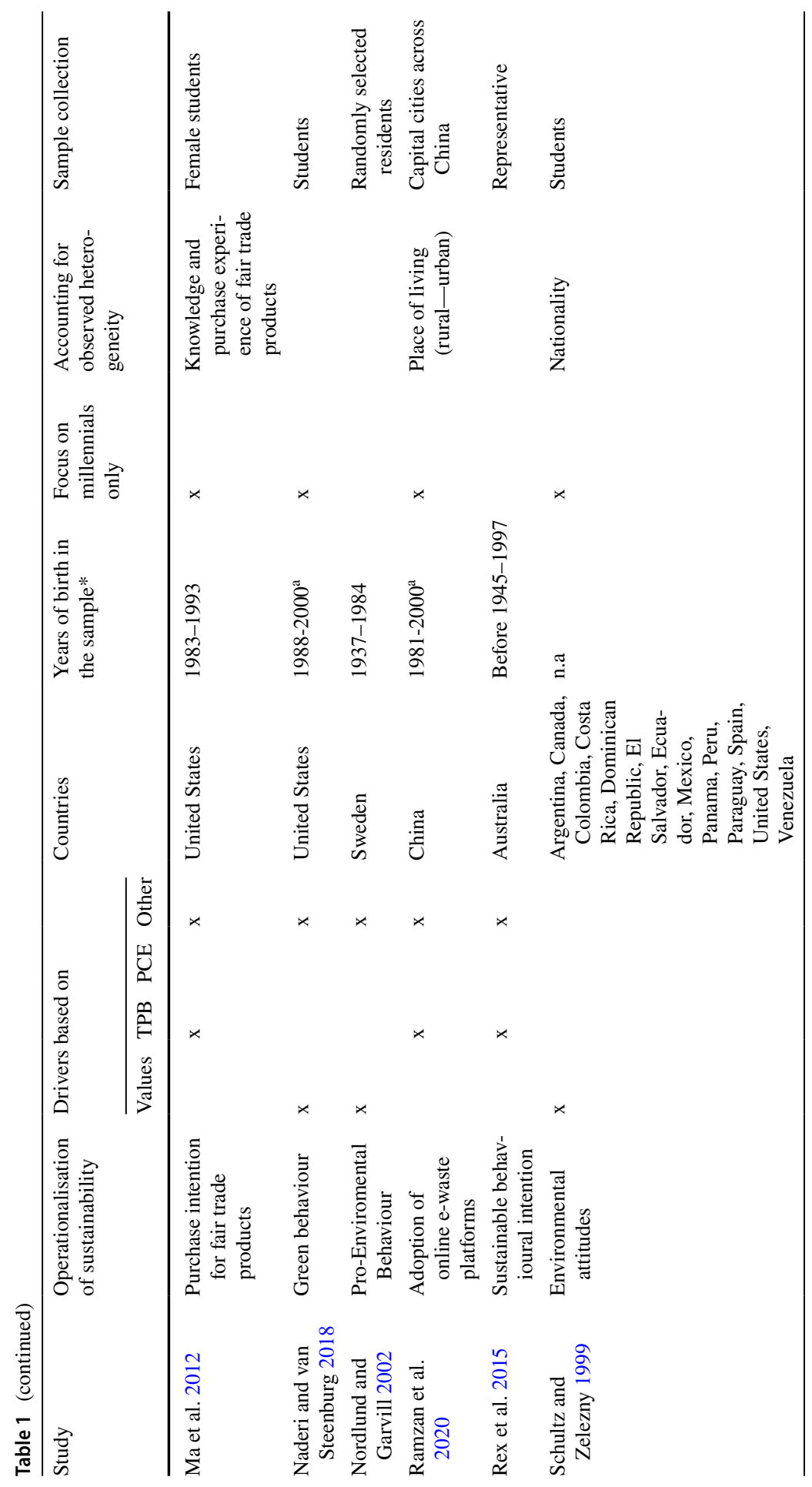




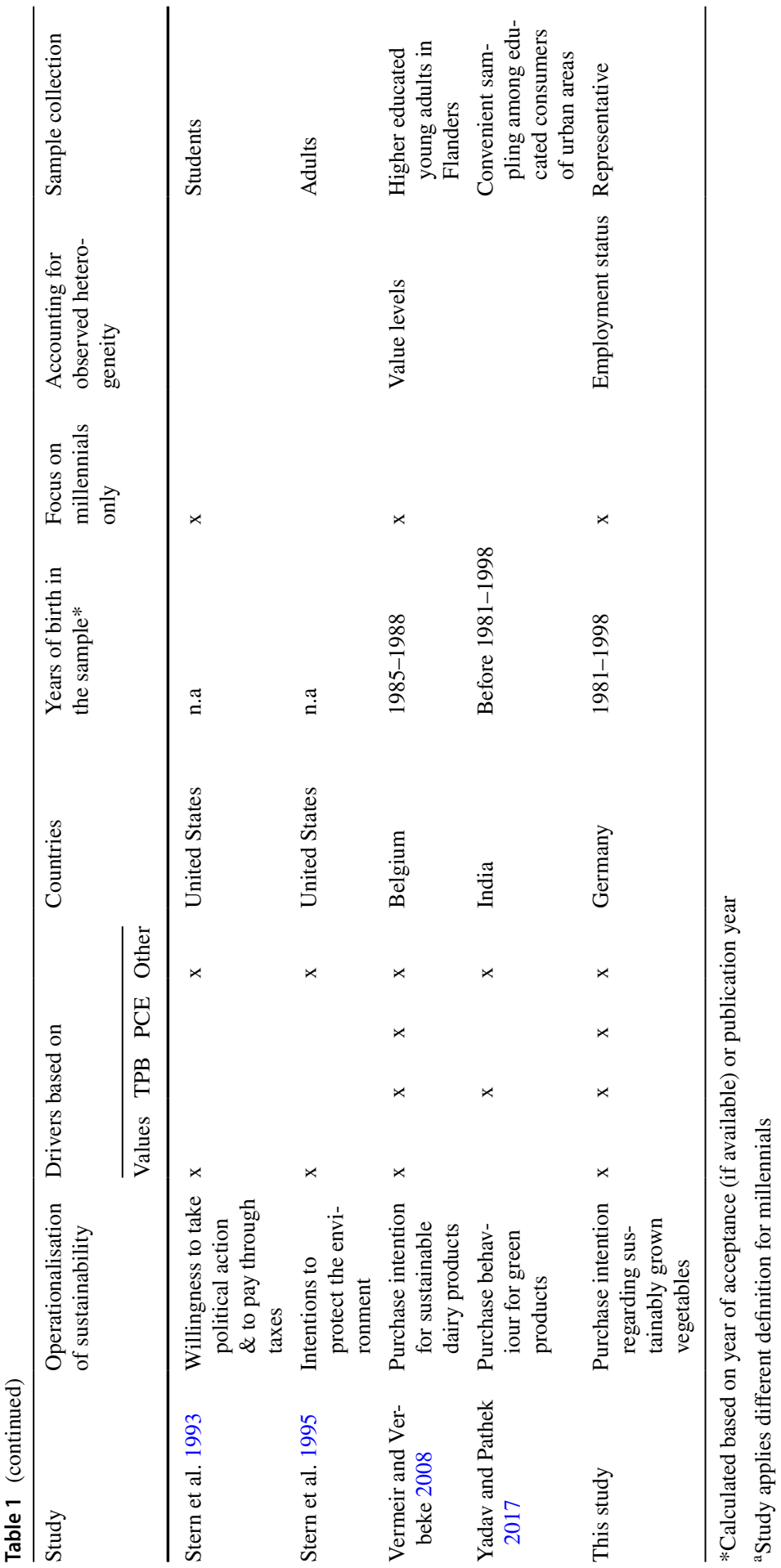


and Verbeke (2008) discuss the impact of Schwartz' s values on purchase intention for sustainable dairy products in Belgium. Some papers use the extension of Stern et al. (1993) on the values of Schwartz (1992) to identify the importance of socialaltruistic values, biospheric orientation and self-interest for the respondents. Stern et al. (1993) discuss the impact of the value system on political action and taxation for US undergraduates while other studies implement them for their research on consequence awareness in selected European countries (de Groot and Steg 2007, 2008).

Naderi and van Steenburg (2018) study the impact of four psychographic variables on millennials' green behaviour. Whereas altruism or risk averseness does not affect green behaviour, they find that millennials who are more frugal and future oriented engage more in green consumption behaviours.

The TPB by Ajzen (1985) has become another favoured framework to explain purchase behaviour based on, among others, values of respondents. For instance, the aforementioned study of Vermeir and Verbeke (2008) refers to TPB as framework. Ma et al. (2012) apply it to link the belief system by Littrell et al. (2005) to purchase intention for fair trade products. Rex et al. (2015) use TPB to assess if internal ethics (Shaw and Shiu 2003) are antecedents for sustainable behavioural intention. Yadav and Pathak (2017) apply India-specific belief measures to model purchase intention for green products via TPB in India.

Interestingly, only four studies (Jaiswal and Kant 2018; Ramzan et al. 2020; Rex et al. 2015, Yadav and Pathak 2017) use the whole generation of millennials, which spans from 1981 to 1998 (VuMa 2018). In contrast, the remaining studies focused on older (e.g., Vermeir and Verbeke 2008) or younger millennials (e.g., Heo and Muralidharan 2019). In addition, some studies explicitly focus on millennials only (e.g., Ramzan et al. 2020; Vermeir and Verbeke 2008), others are broader and analyse millennials together with other generations without further differentiation (Rex et al. 2015).

In our study, we analyse purchase intention of sustainably grown vegetables among millennials in Germany. Against the backdrop of previous studies, our study tries to contribute in the following aspects: first, our survey data differs significantly from other studies in important aspects. As mentioned before, our target demographic are millennials born between 1981 and 1998. Therefore, all studies before 2016, i.e., the vast majority of related research, can only get an incomplete picture of this demographic because a large part of millennials were minors at the time of that study or, as it is the case with Nordlund and Garvill (2002), millennials and member of Generation $\mathrm{X}$ are mixed together. In addition, the database of other studies often consists of students (e.g., Stern et al. 1993; Schultz and Zelezny 1999, Hwang and Griffith 2017), which is a very specific group of a generation. Previous research has shown that millennials are not homogenous regarding values they consider as important. In particular, age or income situations (Gurel-Atay et al. 2010) or entering work life (Asselmann and Specht 2021) may shape values. We therefore abstain from taking a sample of a specific subgroup of millennials but instead take our sample across the whole millennial population. To account for possible differences, we segment millennials into full-time employed and not (yet) full-time employed persons. To the best of our knowledge, most previous research has either considered 
millennials as a uniform segment (e.g., Heo and Muralidharan 2019) or differentiated across countries (e.g., Ma et al. 2012), value levels (Vermeir and Verbeke 2008) or place of living (Ramzan et al. 2020).

Second, to circumvent issues which are typically associated with student or convenient samples, we enlisted an independent data collection institute to get data that represents the social demographic structure of Germany and make our study more comprehensive.

Third, we combine values, TPB, and PCE. We apply the list of values (LOV) proposed by Kahle (1983), which is often used in Marketing to operationalize values (Paetz 2021). Like many other studies, we use TPB by Ajzen (1985) as framework. However, unlike other studies such as Ma et al. (2012), we apply all constructs of TPB (i.e., attitude, subjective norms, and perceived behaviour control (PBC)) in our study. In addition, we add PCE to our framework. PCE was part of previous research concerning sustainable consumption (e.g., Kang et al. 2013, Hwang and Griffith 2017, Jaiswal and Kant 2018) but, although PCE is a key construct for sustainable consumption, literature on the combination of TPB and PCE is very scarce. We are only aware of one study, Vermeir and Verbeke (2008), that uses TPB and PCE in their framework but, in contrast to us, they include values as moderators while we incorporate LOV as antecedents of attitude.

Finally, most of the recent studies, whose respondents have a similar age distribution as our study, take place in India (Yadav and Pathek 2017) or in Anglo-American countries (Valentine and Powers 2013; Rex et al 2015, Hwang and Griffith 2017) with different cultures than that of continental Europe. Values and beliefs are embedded in culture (Grunert and Scherlorn 1990). If studies take place in countries with diverging cultures, the impact of values and beliefs on actions and consumption can differ (Yoon 2009). For instance, Grunert and Scherlorn (1990) find substantial differences between German, Norwegian, and North American respondents.

\section{Theoretical background}

In order to analyse the drivers of sustainable consumption, we draw on several wellestablished constructs such as values, PCE, and the constructs of TPB. To give an overview of our conceptual framework, we visualise our hypothesised influences in Fig. 1.

\subsection{Values}

Values can be seen as "an enduring belief that a specific mode of conduct or endstate of existence is personally or socially preferable to an opposite or converse mode of conduct or end-state of existence" (Rokeach 1973). Values have been proved to be effective antecedents to explain consumer behaviour (Clawson and Vinson 1978), as customers at least partly purchase products that reflect their values (Kahle and Kennedy 1988). Individuals typically refer to values to resolve conflicts or to arrive at a decision. According to Kamakura and Novak (1992), considering values-in 


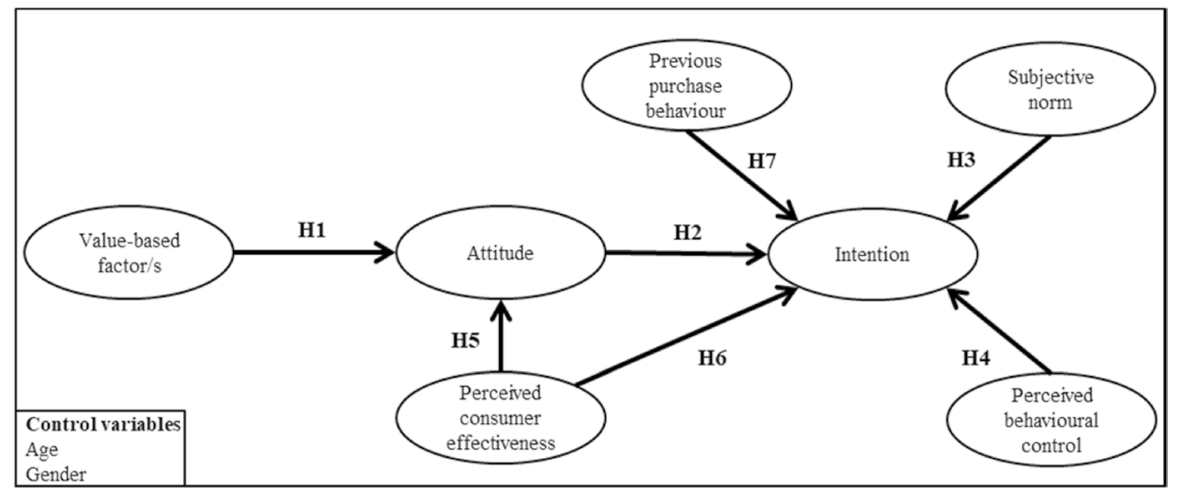

Fig. 1 Conceptual framework

addition to attitudes-leads to a better understanding of consumer behaviour. Most of previous research on sustainable consumption (see Table 1) has employed Schwartz's list of values, which identifies ten values that can be grouped into openness to change, self-transcendence, self-enhancement, and conservatism (Gurel-Atay et al. 2019). In our study, we draw on the LOV by Kahle (1983), which has often been applied in Marketing (Paetz 2021). Similar to Schwartz's (1992) values, LOV also relates to Rokeach's (1973) value scale but includes value scales by Maslow (1954) as well. The resulting LOV consists of nine values ("Self-fulfillment", "Excitement", "Sense of accomplishment", "Self-respect", "Sense of belonging", "Being well-respected", "Security", "Fun and enjoyment", "Warm relationships"). These values are associated with different types of respondents (Kahle 1984; Kahle and Kennedy 1988; Kahle et al. 1988). Whereas "Security" is a deficit value, which is connected to people of no economic and psychological security, "Warm relationship" is an excess value, which is connected to especially women with many friends. In the same manner, "Sense of accomplishment" and "Self-fulfillment" are endorsed by successful middle-aged men with good jobs and high incomes and by young urban professionals, respectively. This is in contrast to respondents who are connected to "Being well-respected" who have a low income and education and are associated to people of age $50+$. "Sense of belonging" is mainly endorsed by women with high school education but middle-income. Young people who value life are connected to "Fun and enjoyment", which is sometimes combined with "Excitement" (Kahle and Kennedy 1988). Finally, "Self-respect" can be considered as general value without specific characteristics of the respondents.

Compared with Schwartz's (1992) norm-activation theory, LOV have several advantages. Whereas Schwartz's values are originally assessed with more than 50 items, LOV only uses less than one fifth which leads to less effort of the respondents. In addition, many of the items for Schwartz's list of values are not relevant for consumer behaviour. Because of that, validity might be lower for Schwartz's values than for LOV as has been shown by Gurel-Atay et al. (2019). A further advantage of LOV is their higher relevance over daily lives (Beatty et al. 1985) compared to other studies such as Rokeach (1973). 
In the following, we refer to different studies using LOV to identify values. Outside of the context of sustainable consumption, Homer and Kahle (1988) applied factor analysis and identified three different sets of values (internal/personal values, external values, and interpersonal values) among 831 food shoppers in the context of natural food shopping. Shim and Eastlick (1998) identify two different sets of values (self-actualizing and social affiliation) for a sample of 5000 households regarding consumer behaviour in shopping malls. McCarty and Shrum (1994) find three sets of values from LOV (self-gratification, fun/enjoyment, security) to be relevant within the recycling context based on a sample of 134 undergraduate students.

\subsection{Hypotheses}

Homer and Kahle (1988) state that values are able to influence attitude and behaviour in a hierarchical manner. This means that values may affect the formation and influence of attitudes, which in turn will be related to behaviour. They find a positive effect for personal and interpersonal values on attitude whereas the effect of external values was negatively related. In contrast to that, both sets of values in Shim and Eastlick's (1998) studies influence attitude in a positive manner. McCarty and Shrum (1994) only find three of their four sets of values to have a significant impact on attitude. Collectivism has a negative impact on "Inconvenience attitude", selfgratification (fun/enjoyment) has a positive (negative) impact on "Importance attitude". Gurel-Atay et al. (2010) show in their 2007 sample that values depend on various factors such as age, education or income: whereas $6 \%$ of respondents below 30 years of age rate "Self-fulfillment" as the most important value, it is the most important value for $22.8 \%$ of respondents above 60 years of age. On the other hand, "Being well-respected" is the most important value for $6.5 \%$ of respondents that fall in the lowest income category, whereas $8.3 \%$ of respondents in the highest income category consider it as important. Classifying millennials by employment status also distinguishes the two groups by age as millennials with full-time employment tend to be older. As previous studies have identified different sets of values, we do keep our hypothesis regarding identified values rather general. We therefore state:

H1a: The identified set(s) of values relate to attitudes towards sustainable consumption.

H1b: The identified set(s) differ between full-time employed and not (yet) fulltime employed millennials.

We make use of the TPB as an explanation framework of purchasing behaviour as it has generally performed well to understand drivers of an individual's voluntary behaviour (Ajzen 1991). Since deciding to buy sustainably is a voluntary decision, the TPB may be applied here (Rex et al. 2015), which has also been supported by other studies in the domain (e.g., Vermeir and Verbeke 2008, Yadav and Pathek 2017). In line with the theory, consumers who view an action as favourable and whose peer group also is fond of it are more likely to engage in that action. Ajzen (1991) builds the TPB upon these ideas but provides a further antecedent, which might affect the likelihood of engaging in the action: perceived behaviour control $(\mathrm{PBC})$. He noticed that sometimes an action is not taken because individuals 
perceive themselves as incapable to do so. As an example, a person sees the benefits of purchasing sustainably, but due to a tense income situation he or she will refrain to do so. In the following, we will discuss the different relationships of the TPB and how they are accounted for in related literature.

According to Ajzen (1991), the more favourable an individual's attitude towards a behaviour the stronger is the individual's intention to perform the behaviour in question. Past research on sustainable consumption unanimously supports this relationship, independent of whether the focus was on millennials (Kang et al. 2013; Ma et al. 2012; Ramzan et al. 2020; Vermeir and Verbeke 2008) or not (Chan and Lau 2002, Rex et al 2015, Yadav and Pathek 2017). For instance, Vermeir and Verbeke (2008) find a positive relationship between attitude towards purchasing sustainable dairy products and the behavioural intention. We therefore state:

H2a: The millennials' attitude towards sustainably grown consumer goods has a positive influence on intention to purchase these goods.

H2b: The relationship between millennials' attitude towards sustainably grown consumer goods and intention to purchase these goods is different for full-time employed and not (yet) full-time employed millennials.

Subjective norm, as another construct within TPB, is a perceived social pressure regarding a certain behaviour (Ajzen 1991). It may hence be relevant for the individual how, e.g., parents, friends, colleagues or society judge the behaviour. In this context, millennials observe that peers expect them to purchase sustainably grown consumer goods and, as a consequence, are motivated to comply with the peers' expectations. Vermeir and Verbeke (2008) did not find high values for subjective norms but a positive effect on intention. In fact, this is in line with the remaining studies (Kang et al. 2013, Ramzan et al. 2020, Chan and Lau 2002, Rex et al 2015, Yadav and Pathek 2017) who find that the opinion of others positively affects purchase intentions of green products and sustainable behavioural intentions, respectively. Please note that Ma et al. (2012) exclude this construct from their study. As millennials who have full-time employment might consider different peers as important, compared to those who are not (yet) fully employed, we aim to analyse whether the influence of the subjective norm can be observed in both groups. Because of the findings from previous research, we assume:

H3a: Subjective norms have a positive influence on millennials' intention to purchase sustainably grown consumer goods.

H3b: The relationship between subjective norms and intention to purchase sustainably grown consumer goods is different for full-time employed and not (yet) full-time employed millennials.

PBC describes how individuals perceive the difficulty for them to perform a certain behaviour (Ajzen 1991). If it seems easy for individuals to perform a certain behaviour, the intention to do so will increase. Whereas previous studies without focus on millennials observe a positive influence of PBC on intention (Chan and Lau 2002, Rex et al. 2015; Yadav and Pathak 2017), findings from the studies with a clear focus on millennials are mixed. Kang et al. (2013) do not find a significant effect of PBC which is in contrast to Ma et al. (2012) and Ramzan et al. (2020) who observe a positive influence of the $\mathrm{PBC}$ on purchase intention. Again, we would like to explore whether the influence of $\mathrm{PBC}$ on intention holds for both groups of 
millennials. According to Naderi and van Steenburg (2018), frugality influences green purchase behaviour as millennials' (financial) resources are limited. On the one hand full-time employed millennials might have a higher budget and could therefore more easily afford to buy sustainably grown vegetables. On the other hand, millennials who are not (yet) fully employed might have more time to look for these products. Since Kang et al. (2013) question their own operationalisation of the PBC construct (which might have caused the insignificant effect), we follow the majority of previous results and state:

H4a: PBC has a positive influence on millennials' intention to purchase sustainably grown consumer goods.

H4b: The relationship between PBC and intention to purchase sustainably grown consumer goods is different for full-time employed and not (yet) full-time employed millennials.

Oftentimes, an attitude behaviour gap might arise. That means that even if millennials have a favourable attitude towards sustainably grown consumer goods, this might not be reflected in their purchase behaviour. This may be due to various reasons such as that sustainable consumption induces some extra efforts from the side of the customer, e.g., sustainable products might not be readily available in every store or the consumer needs to spend more for such products. In addition to that, customers might question whether their sustainable purchase behaviour would help the environment. In this regard, Kang et al. (2013) point to Roberts (1996) who proved the PCE to be an informative construct in describing purchase behaviour. PCE describes whether an individual believes that her or his behaviour can help solving a societal issue (Ellen et al. 1991). In fact, this construct is often used in literature to explain attitudes and intentions regarding environmental issues. Kang et al. (2013) and Jaiswal and Kant (2018) show that consumers who believe that their purchasing behaviour can help the environment are more likely to form a more positive attitude towards sustainable or green products, respectively. We therefore assume:

H5a: For millennials PCE has a positive influence on their attitude towards sustainably grown consumer goods.

H5b: The relationship between PCE and attitude towards sustainably grown consumer goods is different for full-time employed and not (yet) full-time employed millennials.

Among the group of studies that focus on millennials, we observe mixed findings regarding the impact of PCE on intention. Heo and Muralidharan (2019) do not find a significant direct relationship between PCE and purchase intention but an indirect effect via environmental control as mediator. Hwang and Griffiths (2017) find that PCE does not moderate the relationship between attitude and purchase intentions. They argue that millennials already have a strong attitude towards sustainable consumption which increases purchase intentions without further influence. Still, they additionally call for further studies as their analysis is based on 92 observations. This is in contrast to Vermeir and Verbeke (2008) and Jaiswal and Kant (2018) who find that consumers who believe that their actions could make a difference also show stronger purchase intentions towards the sustainable or green product, respectively. Due to the mixed findings, we like to analyse whether PCE has an effect on intention 
among our segments of millennials. We follow the majority of studies which find a positive (in-)direct effect of PCE on intention. In particular, in line with the findings from Vermeir and Verbeke (2008) whose study object (sustainable dairy product) is also located in the food category, we state:

H6a: For millennials PCE has a positive influence on their intention to purchase sustainably grown consumer goods.

H6b: The relationship between PCE and intention to purchase sustainably grown consumer goods is different for full-time employed and not (yet) full-time employed millennials.

Finally, previous purchase behaviour is another variable of interest. According to Ajzen (2002), past behaviour can be used as a predictor of future behaviour or, in the case of the TPB, behavioural intention. However, some authors state that millennials are not very brand loyal and make purchases based on personality and lifestyle fit (Caplan 2005) or product features (Phillips 2007). On the other hand, Gurău (2012) finds evidence that the life stage of the millennials influences loyalty in that students are less loyal than professionals. Furthermore, other studies find strong brand loyalty among millennials if such lifestyle fit is achieved. For instance, in the study conducted by Edelmann and StrategyOne (2010) 70\% of millennials express that they keep coming back to a product or company if they like it. We also think that previous purchases may have an impact on intention in the context of food and green products and hence state:

H7a: The millennials' previous purchase behaviour of sustainably grown consumer goods has a positive influence on their purchase intention to purchase sustainably grown consumer goods.

H7b: The relationship between previous purchase behaviour of sustainably grown consumer goods and purchase intention to purchase sustainably grown consumer goods is different for full-time employed and not (yet) full-time employed millennials.

\section{Method}

\subsection{Data collection}

For the survey, we ask the respondents to visualise buying sustainably grown vegetables, i.e., vegetables that are organic, have a certified origin, are fair trade, and/ or are of local origin. The choice of using vegetables as an example for sustainably grown goods is based on two important aspects: first, vegetables are fast moving consumer goods (FMCG), thus respondents should have much experience purchasing them; Second, vegetables are for many consumers the first FMCG to be associated with sustainable consumption (Padel and Foster 2005).

For the operationalisation of our constructs, we use often applied items in our survey (see Table 2 for the references and the appendix for the specific items) and measure each item with a 7-point Likert scale.

Before starting the main study, we conducted a pretest in the end of June 2018 to control if the operationalization is comprehensible for the respondents and the 
Table 2 Operationalisation of constructs

\begin{tabular}{ll}
\hline Construct & Source of items \\
\hline LOV & Kahle (1983), Homer and Kahle (1988) \\
Attitude & Ajzen and Fishbein (1980) \\
PCE & Roberts (1996) \\
Previous purchase behaviour & Wan et al. (2012) \\
Subjective norm & Ajzen and Fishbein (1980), Vermeir and \\
& Verbeke (2008) \\
PBC & Rex et al. (2015), Yadav and Pathak (2017) \\
Intention & Kim et al. (2013) \\
\hline
\end{tabular}

questions are clearly stated. All items that turned out to not meet the threshold of local fit criteria during the pretest were eliminated from the survey. The main study was conducted from 12th to the 23rd of July 2018 by an independent data collection institute. The goal was to represent the social demographic structure of Germany as good as possible in the survey data. All in all, 319 respondents participated in the survey and after sorting out outliers, we arrived at a total of 312 usable questionnaires.

As mentioned before, getting employed for the first time is an event that induces personality maturation for people (Asselmann and Specht 2021) and therefore can influence their personality and values. Furthermore, Gurău (2012) shows that millennial students evaluate products differently and have a particular loyalty profile compared to millennial professionals or Generation X professionals. We therefore split our data set into respondents with full-time employment and those with no full-time employment. Table 3 give some descriptive statistics of the collected data:

Table 3 Descriptive statistics of the data sets

\begin{tabular}{llll}
\hline & $\begin{array}{l}\text { Unseg- } \\
\text { mented } \\
\text { sample }\end{array}$ & $\begin{array}{l}\text { Full-time } \\
\text { employment }\end{array}$ & $\begin{array}{l}\text { Not full-time } \\
\text { employment }\end{array}$ \\
\hline Respondents & 312 & 188 & 124 \\
Female (in \%) & 48.10 & 39.90 & 60.50 \\
Born 1981-1986 (in \%) & 30.10 & 35.60 & 21.80 \\
$\begin{array}{l}\text { Born 1987-1992 (in \%) } \\
\text { Born 1993-1998 (in \%) }\end{array}$ & 39.10 & 38.30 & 40.30 \\
$\begin{array}{l}\text { Purchase of Vegetables } \\
\text { at least once a week } \\
\text { (in \%) }\end{array}$ & 82.70 & 81.40 & 84.70 \\
$\begin{array}{l}\text { Purchase of Vegetables } \\
\text { multiple times a week } \\
\text { (in \%) }\end{array}$ & 50.30 & 46.80 & 55.60 \\
\hline
\end{tabular}




\subsection{Model evaluation}

We test our hypotheses on three groups as outlined in Table 3. We refer to the whole sample (unsegmented) to test our set of hypotheses concerning the existence of influences (label "a"). When analysing segment-specific differences (label "b"), we refer to our two segment-specific models (full-time and not (yet) full-time employment).

We apply structural equation modelling, one of the commonly used modelling techniques in psychology and economics (Falke et al. 2020) to our three groups. Factor loadings and path coefficients are estimated in SPSS and AMOS (Arbuckle 2014). In line with previous studies (Homer and Kahle 1988; Shim and Eastlick 1998) we first look for latent set of values (=constructs) among LOV by factor analysis. Then we use the emerged constructs in the conceptual model proposed in Fig. 1. According to the exploratory factor analysis (Kaiser-Meyer-Olkin and Measure of Sampling Adequacy criteria are satisfied in all models), we find that two latent constructs are present among the values in the unsegmented sample, four latent constructs for full-time employed, and three for not (yet) full-time employed respondents. So, we conduct a confirmatory factor analysis with all items and hypothesised constructs.

Next, we evaluate the measurement model. Unfortunately, one item in both the unsegmented model and the full-time employment model, and two items in the not (yet) full-time employment model had to be eliminated during the indicator reliability test as their values are below the threshold of 0.4 . Finally, during the discriminant validity test, two constructs in the not (yet) full-time employment model had to be merged into one construct. Table 4 depicts the evaluation of the final measurement models. All Cronbach's alpha values are above the suggested threshold of 0.7 . The average variance extracted (AVE) and composite reliability (CR) values of all other constructs are above the suggested thresholds of 0.5 and 0.6 , respectively, and all final constructs satisfy the Fornell-Larker discriminant criterion.

Finally, we assess the overall fit of our models by computing the usual fit criteria (see Table 5). The RMSEA values of both models are below 0.08 and therefore point towards an acceptable fit.

The value of SRMR is small, indicating a good fit (Bollen 1989). At last, the values of both TLI and CFI are greater than 0.9, also suggesting a good fit (Bollen 1989). We hence conclude that the overall fit of our model is fine.

\section{Results}

In this section, we summarise the results and discuss our findings. Figure 2 illustrates the final models and all estimated path coefficients to make the discussion more comprehensible.

\subsection{Summary of findings}

According to the exploratory factor analysis on LOV, the nine values can be summarised into two latent constructs for the unsegmented model while four and three 

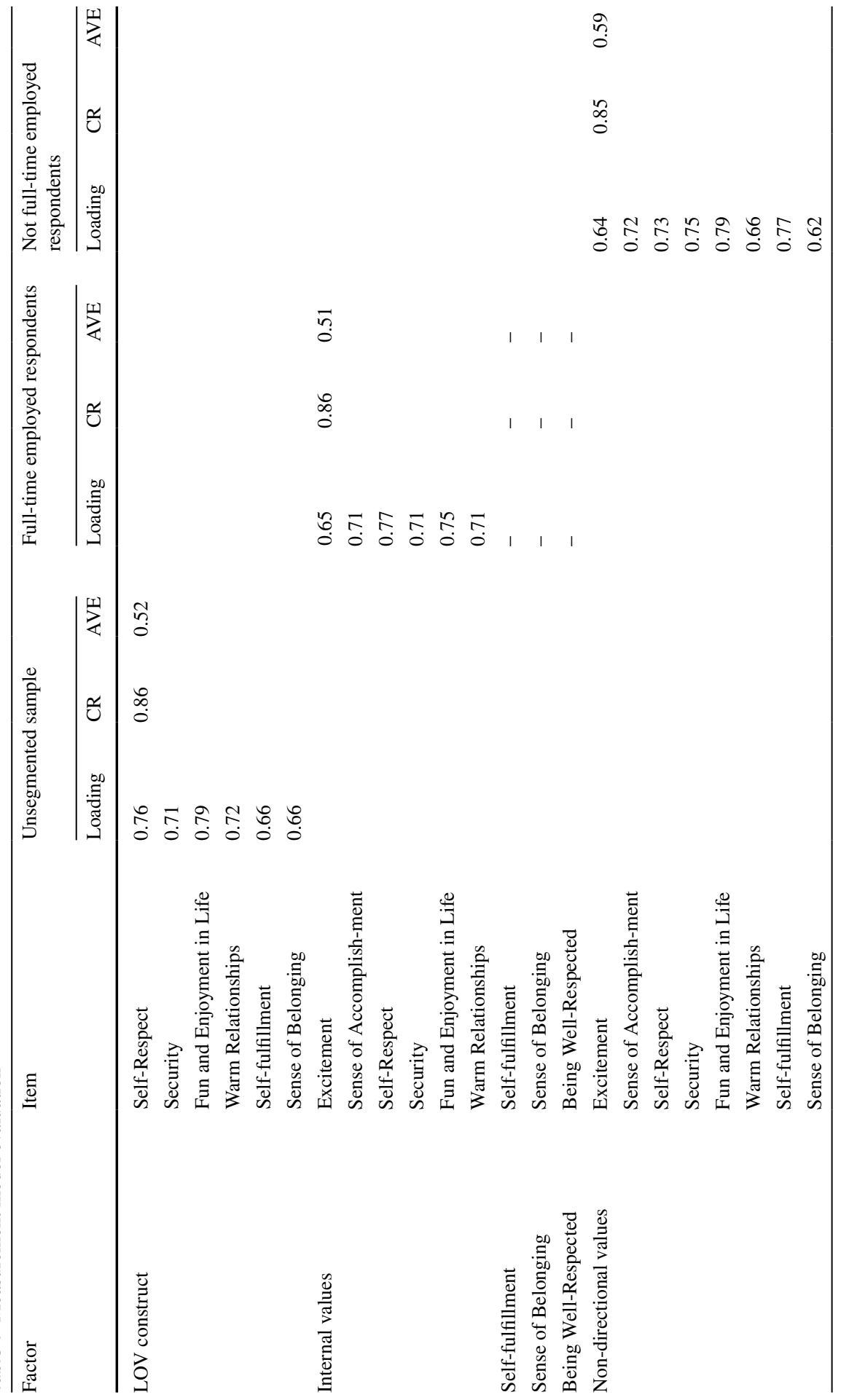

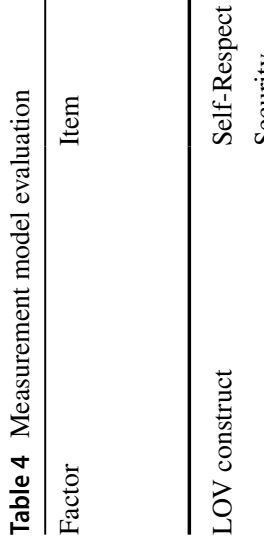

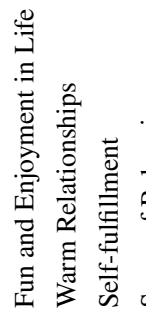

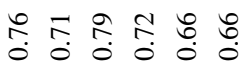




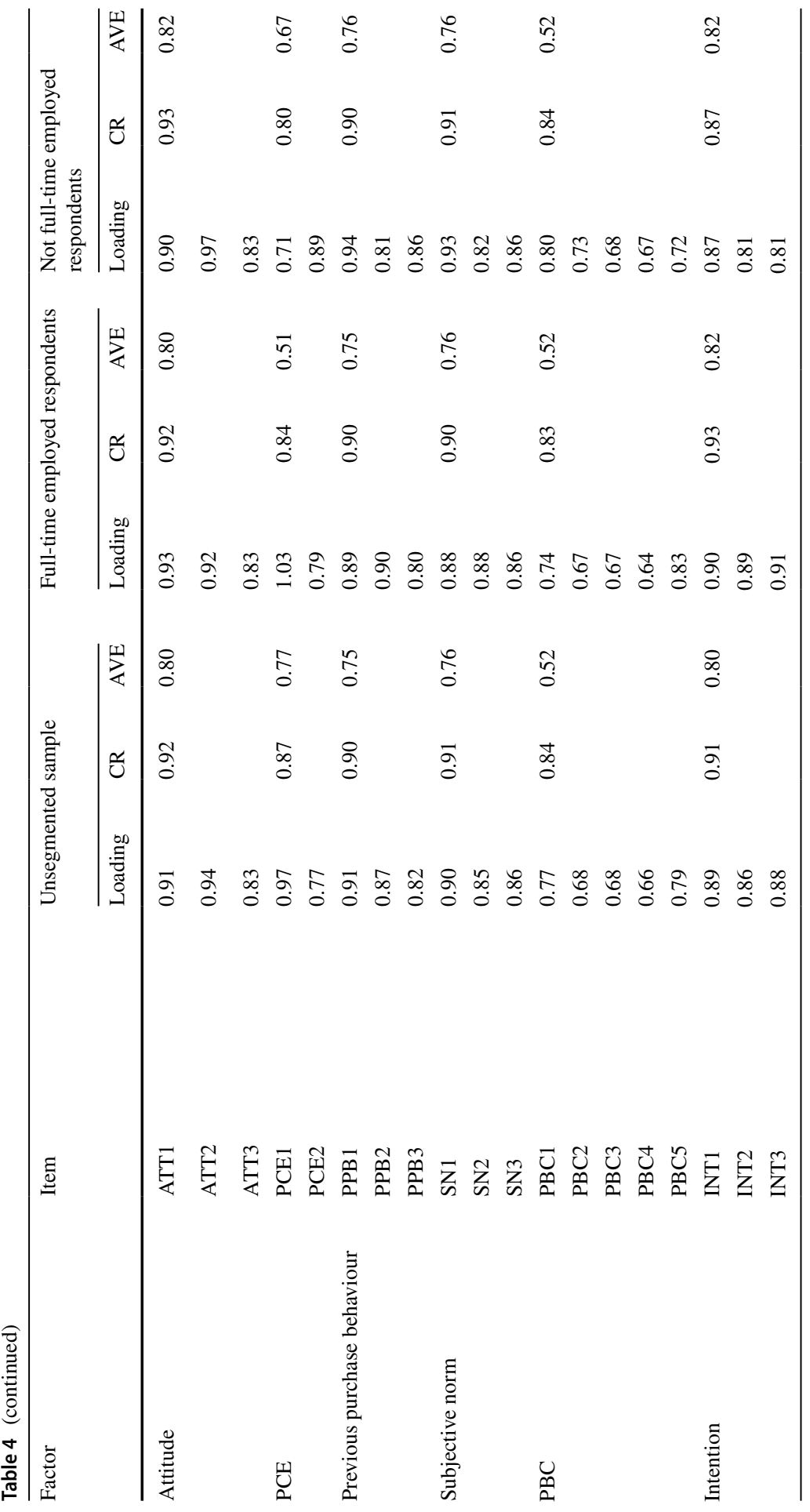


Table 5 Values of various model fit criteria

\begin{tabular}{lccc}
\hline Fit index & $\begin{array}{l}\text { Unseg- } \\
\text { mented } \\
\text { sample }\end{array}$ & $\begin{array}{l}\text { Full-time } \\
\text { employed } \\
\text { respondents }\end{array}$ & $\begin{array}{l}\text { Not full-time } \\
\text { employed respond- } \\
\text { ents }\end{array}$ \\
\hline$\chi^{2}$ & 583.6 & 577.2 & 487.5 \\
$\chi^{2} /$ d.f & 1.99 & 1.64 & 1.52 \\
RMSEA & 0.06 & 0.06 & 0.07 \\
SRMR & 0.07 & 0.06 & 0.09 \\
TLI & 0.93 & 0.92 & 0.90 \\
CFI & 0.94 & 0.94 & 0.92 \\
\hline
\end{tabular}

latent constructs are suggested for the full-time employment and the no full-time employment model, respectively.

In all models, we find that at least one of the LOV constructs has an influence on attitude. This is a clear support for Hypothesis 1a. However, the composition of the constructs is not identical in all models, providing support for Hypotheses 1b. In the model of the full-time employed respondents, the values "Self-fulfillment ", "Sense of belonging", and "Being well-respected" make up separate constructs, all other values load onto a common construct. With the exception of "Security", all remaining values are internal values (Homer and Kahle 1988), which is why we refer to the construct as "internal values". All single-value constructs do not have a significant impact on attitude, but "internal values" do.

On the other hand, in the model of the not (yet) full-time employed respondents, two constructs had to be merged, because the Fornell-Larker criterion suggested a lacking discriminant validity, and the third construct did not pass the model fit evaluation. The final construct consists of all values except for "Being well-respected". This is not surprising because "Being well-respected" is associated with people of age group 50+ with little occupational prestige (Kahle and Kennedy 1988). Since we find more than one underlying dimension, we refer to this construct as "nondirectional values".

We also find a significant path coefficient from attitude to intention in our unsegmented model, which is in line with Hypothesis 2 a that the attitude of millennials towards sustainable consumption influences their purchase intention. In addition, we observe a significant positive path coefficient in both segment-specific models, so Hypothesis $2 b$ has to be rejected.

Concerning the impact of the subjective norm and PBC, both antecedents have an influence on purchasing intention in the unsegmented model, supporting Hypotheses $3 \mathrm{a}$ and $4 \mathrm{a}$. On the other hand. the results differ between the segment-specific models, also supporting Hypotheses $3 \mathrm{~b}$ and $4 \mathrm{~b}$. For the full-time employed respondents, we find a significant impact of the subjective norm on purchase intention and no significant impact of PBC on it. On the other hand, in case of the not (yet) full-time employed respondents, the path coefficient from subjective norm to intention is not significant while the path coefficient form PBC to intention is significant.

Regarding PCE, we find a significantly positive influence on the attitude towards sustainable consumption, but no significant influence on purchase intention in the 
Unsegemented sample

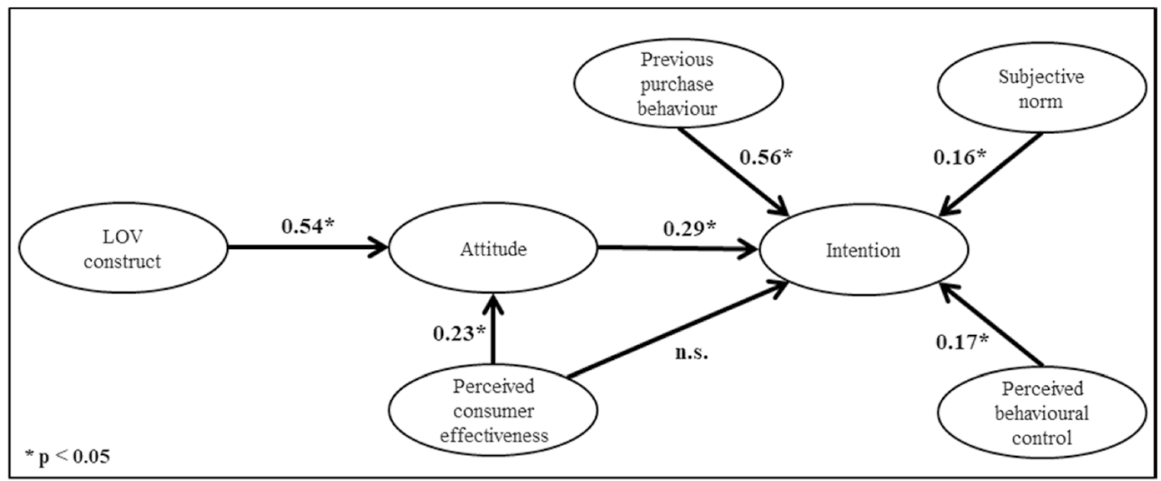

Full-time employed respondents

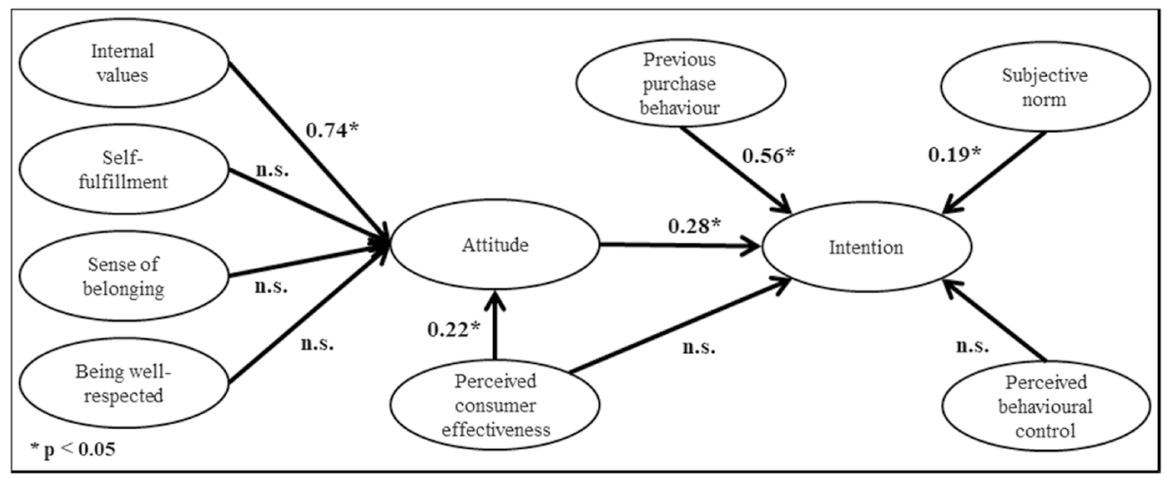

Not full-time employed respondents

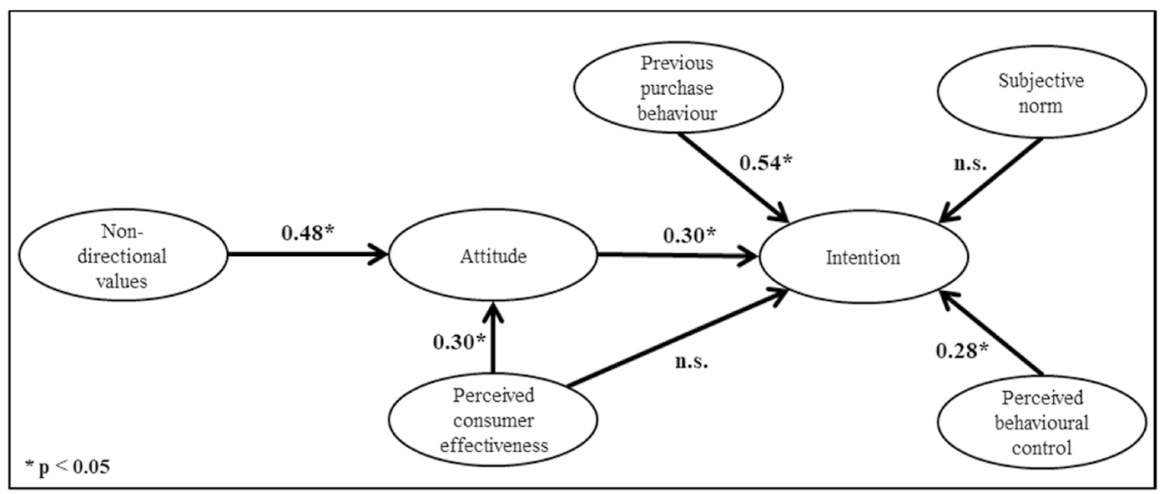

Fig. 2 Results of the structural models

unsegmented model. As a consequence, we find support for Hypothesis 5a, that high PCE positively affects the attitude, but we have to reject Hypothesis 6a $(p>0.05)$. As the segment-specific models do not diverge concerning PCE, both Hypothesis $5 \mathrm{~b}$ and $6 \mathrm{~b}$ had to be rejected. 
Finally, we find support from the unsegmented model for Hypothesis 7a that the previous purchasing behaviour affects purchase intention, i.e., a high frequency of sustainably grown vegetables purchases in the past increases the purchase intention for the future. Both path coefficient of the segment-specific models are also significant and close to each other, so we have to reject Hypothesis $7 \mathrm{~b}$.

\subsection{Discussion and implications}

We find that attitude influences the intention of the two analysed segments of millennials concerning sustainable consumption. Interestingly, other constructs differ for the two segments, i.e., the subjective norm influences intention among the full-time employed millennials while PBC influences the not (yet) fully employed millennials' intention. Furthermore, we find that LOV by Kahle (1983) can be summarised into different constructs, such as "internal values, "Self-fulfillment", "Sense of belonging", "Being wellrespected" for the segment of full-time respondents and "nondirectional values" for the segment of not full-time employed respondents. For full-time employed millennials, internal values positively influence attitude towards sustainable consumption whereas external values such as "Sense of Belonging" or "Being well-respected" show no significant impact. In contrast to that, values that influence attitude of not (yet) full-time employed millennials are non-directional and constitute of internal and external values. The fact that "Being well-respected" is not significant among the fully employed millennials and is not part of the reduced set of values among the not-fully employed millennials is not surprising as this value is associated to people of age $50+$. In contrast, Vermeir and Verbeke (2008) do not find significant differences concerning the impact of different values scores (high vs. low) on the attitude-intention-relationship. Reasons may be the different study design (the authors use value scores as base for segmentation) and the different sample (respondents were in the age group of 19-22 who live in Flanders). People who cherish internal values think that they control or at least influence the impact of their actions (Madrigal and Kahle 1994), which holds for both groups. Similar to that, we find that PCE significantly impacts attitude for the two groups. Apparently, the more millennials belief of being able to help finding solutions for the problems of society the more positive is their attitude regarding sustainable consumption. Finally, we find for both segments of millennials that previous purchases of sustainably grown vegetables increases the intention of future purchases.

Overall, this proves once again that Ajzen's (1985) TPB can model the decision-making process very well. As a result of that, future studies in this area are well advised to consider the TPB in their conceptual framework. Furthermore, our results show that millennials' intention are influenced by values with attitudes as a mediator. Last but not least, we can build on previous research (e.g., Gurel-Atay et al. 2010) which shows that values depend on various factors such as age, education or income. Due to that, we distinguish between full-time employed and not (yet) full time employed millennials and find that the employment status is suited as a segmentation base.

Advertising and product managers are interested in understanding the target audience of their products as they construct their marketing efforts with the values of the audience in mind. As the purchasing power of millennials is increasing over the next years (Smith 
2012), they become an important target group. This study helps managers to understand which values and further factors influence the purchase intention of millennials. In this regard, marketers could target (prospective) customers on social media by selecting age groups, employment status, and interests. Once the marketer defined the target group, marketing activities should be coherently tailored for a specific audience, i.e., millennials or subgroups thereof. In the following, we show how our findings can be translated into managerial implications. As we learn from our analysis, we can segment millennials into those that have a full-time employment and those who are not (yet) fully employed. Let us give some examples as to where the two segments can be addressed in the same manner and how marketers should differentiate across the segments. We observe for both segments a positive relationship between a set of values on attitudes. Messages like "You can make a difference" that are directed at "internal values" for millennials should be considered in communication channels such as, e.g., social media or television ads. According to Homer and Kahle (1988), people who place high importance on these values want to have as much control over their lives as possible, including which food to eat and where to shop them. They will also take extra effort to purchase the perceived best food for them, their relatives, and society. Along these lines, messages should stress that the consumer has the control of her/his (sustainable) consumption habits and can have a positive impact on the environment if she or he behaves in a certain manner. As an example, marketers could use a claim in line with "It is in your control to combat climate change" to engage fully employed millennials. If millennials are targeted who are not (yet) fully employed, external values such as "Sense of Belonging" may also be triggered in addition. The significant influence of PCE on attitude in both segments further establishes the notion that control over food purchase is an important antecedent for attitude among millennials. Therefore, managers should not only communicate that a product is sustainable, but also inform the customers, i.e., millennials, how purchasing this product might help to solve or at least reduce social and environmental problems. This way, millennials can be convinced that their sustainable consumption has a positive impact on society which also leads to a more positive attitude towards the product and higher purchase intentions. Overall, ensuring that millennials (start to) purchase sustainably grown vegetables is vital, as past purchase behaviour positively influences future purchase intentions in both segments. As our model shows, PBC is a factor with a positive impact on purchase intention of sustainably grown vegetables if millennials are not full-time employed (yet). To guarantee that this group is able to purchase these vegetables, food stores should make sure that these products are constantly available (Vermeir and Verbeke 2008) at an affordable price. Finally, subjective norms positively influence purchase intentions of the full-time employed millennials. Marketers should make sure that this group of millennials and their reference groups are present in advertising efforts to benefit from this influence. For instance, they could use testimonials or influencer marketing to integrate people that are viewed as part of millennials' peers to make advertising claims more trustworthy. All in all, we find several influences in the intention building process that deal with millennials wanting to have control over their purchasing behaviour: the significant influences of internal values and PCE on attitude and additionally, for the not (yet) fully employed segment, the influence of PCB on intention. As Homer and Kahle (1988) state, people who lay high importance on internal values want to have control over the consumption and go through extra length to get the best 
food for themselves and presumably for their most important family members (spouse, children, parents). Therefore, marketers of sustainably grown vegetables should not only show how purchases could help the society but especially emphasize importance for the families of millennials.

\section{Conclusions and limitations}

Millennials grew up with different values than previous generations (e.g., Parment 2012). Still, as previous studies show (e.g., Gurău et al. 2012), millennials are not homogenous. In fact, millennials who begin to work start a new episode in their lives which can impact their personality traits (Asselmann and Specht 2021) and how they value life. Earning their own money may in addition mean that they can act to their most important values. The goal of our study was therefore to find which set of values influence the building of attitude of millennials and how attitude affects the purchase intention concerning sustainable consumption. In doing so, we differentiate millennials into two groups (full-time employed millennials vs. not (yet) fully employed millennials). Building on LOV (Kahle 1983), the TPB (Ajzen 1985), and PCE, we construct a framework to understand how the complex interactions between values and behaviour work. By means of three models, we analysed data that represents the age group of the millennials in Germany well. Our results show how millennials can be divided into already full-time employed and not (yet) full-time employed persons. Moreover, we examine the cohort as a whole first, then use previous research to justify the possibility of individual differences between full-time employed and not (yet) full time employed millennials. Due to varying results in these three analysed models, we think that this study makes valuable contributions to literature. An important finding is the importance of control for both groups. PCE and interval values, which are cherished by people who want to have as much control as possible over all aspects of their lives (Homer and Kahle 1988), impact attitude for both groups. Moreover, PBC also influences purchase intention for not fully employed millennials. On the other hand, these groups differ with respect to the effect of external values, which are only important for not (yet) full-time employed millennials, and subjective norms, which only influence purchase intentions among full-time employed respondents. This study is among the few that try to link the values of the generation called millennials to the purchase intention they form. Furthermore, to the best of our knowledge, this paper is the only recent one whose respondents represent the whole generation of millennials. The generation of millennials is now slowly shifting from being educated to being employed and is therefore a big market that will rise in importance in the near future.

Of course, our study is not without limitations and thus provides interesting avenues for further research. We examined values, attitude and purchase intentions to sustainably grown vegetables because food is generally associated with sustainable products and the majority of customers are experienced buying from this product category. Still, results might be different when other product categories such as durables are involved. In addition, comparing whether and how millennials might differ from other generations like Generation X or Generation $\mathrm{Z}$ in terms of existing values and how they 
influence the building of attitude towards sustainable consumption might be of interest. Finally, we used LOV to measure millennials' values. In a comparison to the original Schwartz value scale, Gurel-Atay et al. (2019) preferred the LOV. Furthermore, in an attempt to reduce the length and difficulties that respondents with little or no education had with the questionnaire, a shortened version consisting of 21 items has been developed (Schwartz 2003). It would be interesting to see whether results hold if the full or a reduced version (21 items) of the Schwartz value scale would have been used instead.

\section{Appendix}

\section{Measurement Items}

\begin{tabular}{|c|c|c|c|c|c|}
\hline \multirow[t]{2}{*}{ Factor } & \multirow[t]{2}{*}{ Item Name } & \multirow[t]{2}{*}{ Item } & \multicolumn{3}{|c|}{ Descriptive statistics } \\
\hline & & & $\begin{array}{l}\text { Unsegmented } \\
\text { sample }\end{array}$ & $\begin{array}{l}\text { Full-time } \\
\text { employed }\end{array}$ & $\begin{array}{l}\text { Not (yet) } \\
\text { full-time } \\
\text { employed }\end{array}$ \\
\hline \multirow[t]{9}{*}{ LOV } & Excitement & $\begin{array}{r}\text { To experience } \\
\text { thrills in life }\end{array}$ & $\begin{array}{l}\text { Mean: } 5.15 \\
\text { SD: } 1.22\end{array}$ & $\begin{array}{l}\text { Mean: } 5.16 \\
\text { SD: } 1.23\end{array}$ & $\begin{array}{l}\text { Mean: } 5.14 \\
\text { SD: } 1.21\end{array}$ \\
\hline & $\begin{array}{l}\text { Sense of } \\
\text { Accomplish- } \\
\text { ment }\end{array}$ & $\begin{array}{l}\text { To be success- } \\
\text { ful in what } \\
\text { you want } \\
\text { to do }\end{array}$ & $\begin{array}{l}\text { Mean: } 5.43 \\
\text { SD: } 1.29\end{array}$ & $\begin{array}{l}\text { Mean: } 5.45 \\
\text { SD: } 1.31\end{array}$ & $\begin{array}{l}\text { Mean: } 5.40 \\
\text { SD: } 1.25\end{array}$ \\
\hline & Self-Respect & $\begin{array}{c}\text { To take pride in } \\
\text { yourself and } \\
\text { be contented }\end{array}$ & $\begin{array}{l}\text { Mean: } 5.66 \\
\text { SD: } 1.29\end{array}$ & $\begin{array}{l}\text { Mean: } 5.67 \\
\text { SD: } 1.26\end{array}$ & $\begin{array}{l}\text { Mean: } 5.64 \\
\text { SD: } 1.33\end{array}$ \\
\hline & Security & $\begin{array}{l}\text { To be safe and } \\
\text { secure from } \\
\text { disaster and } \\
\text { attacks }\end{array}$ & $\begin{array}{l}\text { Mean: } 5.76 \\
\text { SD: } 1.26\end{array}$ & $\begin{array}{l}\text { Mean: } 5.70 \\
\text { SD: } 1.27\end{array}$ & $\begin{array}{l}\text { Mean: } 5.85 \\
\text { SD: } 1.26\end{array}$ \\
\hline & $\begin{array}{l}\text { Fun and Enjoy- } \\
\text { ment in Life }\end{array}$ & $\begin{array}{c}\text { To live a com- } \\
\text { fortable and } \\
\text { happy life }\end{array}$ & $\begin{array}{l}\text { Mean: } 5.97 \\
\text { SD: } 1.25\end{array}$ & $\begin{array}{l}\text { Mean: } 5.94 \\
\text { SD: } 1.24\end{array}$ & $\begin{array}{l}\text { Mean: } 6.02 \\
\text { SD: } 1.26\end{array}$ \\
\hline & $\begin{array}{l}\text { Warm Relation- } \\
\text { ships }\end{array}$ & $\begin{array}{l}\text { To have deep } \\
\text { relationships } \\
\text { and close } \\
\text { friendships }\end{array}$ & $\begin{array}{l}\text { Mean: } 5.70 \\
\text { SD: } 1.22\end{array}$ & $\begin{array}{l}\text { Mean: } 5.70 \\
\text { SD: } 1.15\end{array}$ & $\begin{array}{l}\text { Mean: } 5.72 \\
\text { SD: } 1.33\end{array}$ \\
\hline & Self-fulfillment & $\begin{array}{l}\text { To find peace } \\
\text { of mind and } \\
\text { use the given } \\
\text { talent in an } \\
\text { optimal way }\end{array}$ & $\begin{array}{l}\text { Mean: } 5.52 \\
\text { SD: } 1.29\end{array}$ & $\begin{array}{l}\text { Mean: } 5.51 \\
\text { SD: } 1.23\end{array}$ & $\begin{array}{l}\text { Mean: } 5.52 \\
\text { SD: } 1.35\end{array}$ \\
\hline & $\begin{array}{l}\text { Sense of } \\
\text { Belonging }\end{array}$ & $\begin{array}{l}\text { To be accepted } \\
\text { and wanted } \\
\text { by family, } \\
\text { friends, and } \\
\text { society }\end{array}$ & $\begin{array}{l}\text { Mean: } 5.38 \\
\text { SD: } 1.28\end{array}$ & $\begin{array}{l}\text { Mean: } 5.31 \\
\text { SD: } 1.27\end{array}$ & $\begin{array}{l}\text { Mean: } 5.50 \\
\text { SD: } 1.29\end{array}$ \\
\hline & $\begin{array}{l}\text { Being Well- } \\
\text { Respected* }\end{array}$ & $\begin{array}{l}\text { To be admired } \\
\text { and recog- } \\
\text { nised }\end{array}$ & $\begin{array}{l}\text { Mean: } 4.82 \\
\text { SD: } 1.38\end{array}$ & $\begin{array}{l}\text { Mean: } 4.90 \\
\text { SD: } 1.37\end{array}$ & $\begin{array}{l}\text { Mean: } 4.70 \\
\text { SD: } 1.40\end{array}$ \\
\hline
\end{tabular}




\begin{tabular}{|c|c|c|c|c|c|}
\hline \multirow[t]{2}{*}{ Factor } & \multirow[t]{2}{*}{ Item Name } & \multirow[t]{2}{*}{ Item } & \multicolumn{3}{|c|}{ Descriptive statistics } \\
\hline & & & $\begin{array}{l}\text { Unsegmented } \\
\text { sample }\end{array}$ & $\begin{array}{l}\text { Full-time } \\
\text { employed }\end{array}$ & $\begin{array}{l}\text { Not (yet) } \\
\text { full-time } \\
\text { employed }\end{array}$ \\
\hline \multirow[t]{3}{*}{ Attitude } & ATT1 & $\begin{array}{l}\text { The idea of } \\
\text { purchasing } \\
\text { sustain- } \\
\text { ably grown } \\
\text { vegetables } \\
\text { is: extremely } \\
\text { bad (1) - } \\
\text { extremely } \\
\text { good (7) }\end{array}$ & $\begin{array}{l}\text { Mean: } 5.96 \\
\text { SD: } 1.25\end{array}$ & $\begin{array}{l}\text { Mean: } 5.90 \\
\text { SD: } 1.31\end{array}$ & $\begin{array}{l}\text { Mean: } 6.06 \\
\text { SD: } 1.17\end{array}$ \\
\hline & ATT2 & $\begin{array}{l}\text { The idea of } \\
\text { purchasing } \\
\text { sustain- } \\
\text { ably grown } \\
\text { vegetables } \\
\text { is: extremely } \\
\text { foolish (1) } \\
\text { - extremely } \\
\text { wise (7) }\end{array}$ & $\begin{array}{l}\text { Mean: } 5.82 \\
\text { SD: } 1.32\end{array}$ & $\begin{array}{l}\text { Mean: } 5.81 \\
\text { SD: } 1.35\end{array}$ & $\begin{array}{l}\text { Mean: } 5.83 \\
\text { SD: } 1.28\end{array}$ \\
\hline & ATT3 & $\begin{array}{l}\text { The idea of } \\
\text { purchasing } \\
\text { sustain- } \\
\text { ably grown } \\
\text { vegetables } \\
\text { is: extremely } \\
\text { unfavour- } \\
\text { able (1) } \\
\text { - extremely } \\
\text { favourable (7) }\end{array}$ & $\begin{array}{l}\text { Mean: } 5.86 \\
\text { SD: } 1.41\end{array}$ & $\begin{array}{l}\text { Mean: } 5.87 \\
\text { SD: } 1.36\end{array}$ & $\begin{array}{l}\text { Mean: } 5.85 \\
\text { SD: } 1.48\end{array}$ \\
\hline \multirow[t]{2}{*}{ PCE } & $\mathrm{PCE} 1^{\mathrm{R}}$ & $\begin{array}{l}\text { For a single } \\
\text { consumer it is } \\
\text { impossible to } \\
\text { do some- } \\
\text { thing against } \\
\text { environmental } \\
\text { pollution }\end{array}$ & $\begin{array}{l}\text { Mean: } 4.23 \\
\text { SD: } 1.88\end{array}$ & $\begin{array}{l}\text { Mean: } 4.12 \\
\text { SD: } 1.94\end{array}$ & $\begin{array}{l}\text { Mean: } 4.40 \\
\text { SD: } 1.78\end{array}$ \\
\hline & PCE $2{ }^{R}$ & $\begin{array}{l}\text { My actions do } \\
\text { not make a } \\
\text { difference } \\
\text { because a } \\
\text { single person } \\
\text { cannot influ- } \\
\text { ence the } \\
\text { environmental } \\
\text { pollution and } \\
\text { the problems } \\
\text { with natural } \\
\text { resources }\end{array}$ & $\begin{array}{l}\text { Mean: } 4.45 \\
\text { SD: } 1.89\end{array}$ & $\begin{array}{l}\text { Mean: } 4.32 \\
\text { SD: } 1.88\end{array}$ & $\begin{array}{l}\text { Mean: } 4.64 \\
\text { SD: } 1.90\end{array}$ \\
\hline
\end{tabular}




\begin{tabular}{|c|c|c|c|c|c|}
\hline \multirow[t]{2}{*}{ Factor } & \multirow[t]{2}{*}{ Item Name } & \multirow[t]{2}{*}{ Item } & \multicolumn{3}{|c|}{ Descriptive statistics } \\
\hline & & & $\begin{array}{l}\text { Unsegmented } \\
\text { sample }\end{array}$ & $\begin{array}{l}\text { Full-time } \\
\text { employed }\end{array}$ & $\begin{array}{l}\text { Not (yet) } \\
\text { full-time } \\
\text { employed }\end{array}$ \\
\hline \multirow[t]{3}{*}{$\begin{array}{l}\text { Previous } \\
\text { purchase } \\
\text { behaviour }\end{array}$} & PPB1 & $\begin{array}{l}\text { I have been } \\
\text { purchasing } \\
\text { sustainably } \\
\text { grown veg- } \\
\text { etables at a } \\
\text { regular basis }\end{array}$ & $\begin{array}{l}\text { Mean: } 4.39 \\
\text { SD: } 1.60\end{array}$ & $\begin{array}{l}\text { Mean: } 4.40 \\
\text { SD: } 1.65\end{array}$ & $\begin{array}{l}\text { Mean: } 4.38 \\
\text { SD: } 1.52\end{array}$ \\
\hline & PPB2 & $\begin{array}{l}\text { I have been } \\
\text { purchasing } \\
\text { sustainably } \\
\text { grown veg- } \\
\text { etables for my } \\
\text { daily needs }\end{array}$ & $\begin{array}{l}\text { Mean: } 4.38 \\
\text { SD: } 1.59\end{array}$ & $\begin{array}{l}\text { Mean: } 4.36 \\
\text { SD: } 1.65\end{array}$ & $\begin{array}{l}\text { Mean: } 4.42 \\
\text { SD: } 1.49\end{array}$ \\
\hline & PPB3 & $\begin{array}{l}\text { I have been } \\
\text { purchasing } \\
\text { sustainably } \\
\text { grown veg- } \\
\text { etables over } \\
\text { the past four } \\
\text { weeks }\end{array}$ & $\begin{array}{l}\text { Mean: } 4.74 \\
\text { SD: } 1.67\end{array}$ & $\begin{array}{l}\text { Mean: } 4.78 \\
\text { SD: } 1.71\end{array}$ & $\begin{array}{l}\text { Mean: } 4.68 \\
\text { SD: } 1.61\end{array}$ \\
\hline \multirow[t]{3}{*}{$\begin{array}{l}\text { Subjective } \\
\text { norm }\end{array}$} & SN1 & $\begin{array}{l}\text { Most people } \\
\text { who are } \\
\text { important to } \\
\text { me think I } \\
\text { should pur- } \\
\text { chase sustain- } \\
\text { ably grown } \\
\text { vegetables }\end{array}$ & $\begin{array}{l}\text { Mean: } 4.05 \\
\text { SD: } 1.57\end{array}$ & $\begin{array}{l}\text { Mean: } 4.07 \\
\text { SD: } 1.62\end{array}$ & $\begin{array}{l}\text { Mean: } 4.02 \\
\text { SD: } 1.49\end{array}$ \\
\hline & SN2 & $\begin{array}{l}\text { Most people } \\
\text { who are } \\
\text { important to } \\
\text { me would } \\
\text { want me to } \\
\text { purchase } \\
\text { sustainably } \\
\text { grown vegeta- } \\
\text { bles }\end{array}$ & $\begin{array}{l}\text { Mean: } 4.04 \\
\text { SD: } 1.61\end{array}$ & $\begin{array}{l}\text { Mean: } 4.09 \\
\text { SD: } 1.66\end{array}$ & $\begin{array}{l}\text { Mean: } 3.95 \\
\text { SD: } 1.55\end{array}$ \\
\hline & SN3 & $\begin{array}{l}\text { Society thinks } \\
\text { I should pur- } \\
\text { chase sustain- } \\
\text { ably grown } \\
\text { vegetables }\end{array}$ & $\begin{array}{l}\text { Mean: } 4.06 \\
\text { SD: } 1.56\end{array}$ & $\begin{array}{l}\text { Mean: } 4.13 \\
\text { SD: } 1.61\end{array}$ & $\begin{array}{l}\text { Mean: } 3.94 \\
\text { SD: } 1.50\end{array}$ \\
\hline
\end{tabular}




\begin{tabular}{|c|c|c|c|c|c|}
\hline \multirow[t]{2}{*}{ Factor } & \multirow[t]{2}{*}{ Item Name } & \multirow[t]{2}{*}{ Item } & \multicolumn{3}{|c|}{ Descriptive statistics } \\
\hline & & & $\begin{array}{l}\text { Unsegmented } \\
\text { sample }\end{array}$ & $\begin{array}{l}\text { Full-time } \\
\text { employed }\end{array}$ & $\begin{array}{l}\text { Not (yet) } \\
\text { full-time } \\
\text { employed }\end{array}$ \\
\hline \multirow[t]{6}{*}{$\overline{\mathrm{PBC}}$} & PBC1 & $\begin{array}{l}\text { If I wanted } \\
\text { to, I would } \\
\text { not have } \\
\text { problems } \\
\text { purchasing } \\
\text { sustainably } \\
\text { grown vegeta- } \\
\text { bles }\end{array}$ & $\begin{array}{l}\text { Mean: } 5.17 \\
\text { SD: } 1.42\end{array}$ & $\begin{array}{l}\text { Mean: } 5.26 \\
\text { SD: } 1.43\end{array}$ & $\begin{array}{l}\text { Mean: } 5.03 \\
\text { SD: } 1.40\end{array}$ \\
\hline & $\mathrm{PBC} 2$ & $\begin{array}{l}\text { I have full } \\
\text { control over } \\
\text { whether or } \\
\text { not I purchase } \\
\text { sustainably } \\
\text { grown vegeta- } \\
\text { bles }\end{array}$ & $\begin{array}{l}\text { Mean: } 5.26 \\
\text { SD: } 1.33\end{array}$ & $\begin{array}{l}\text { Mean: } 5.40 \\
\text { SD: } 1.30\end{array}$ & $\begin{array}{l}\text { Mean: } 5.05 \\
\text { SD: } 1.36\end{array}$ \\
\hline & PBC3 & $\begin{array}{l}\text { It is completely } \\
\text { up to me } \\
\text { whether or } \\
\text { not I purchase } \\
\text { sustainably } \\
\text { grown vegeta- } \\
\text { bles }\end{array}$ & $\begin{array}{l}\text { Mean: } 1.44 \\
\text { SD: } 5.35\end{array}$ & $\begin{array}{l}\text { Mean: } 5.41 \\
\text { SD: } 1.46\end{array}$ & $\begin{array}{l}\text { Mean: } 5.27 \\
\text { SD: } 1.40\end{array}$ \\
\hline & PBC4 & $\begin{array}{l}\text { I have the time } \\
\text { to purchase } \\
\text { sustainably } \\
\text { grown vegeta- } \\
\text { bles }\end{array}$ & $\begin{array}{l}\text { Mean: } 5.07 \\
\text { SD: } 1.41\end{array}$ & $\begin{array}{l}\text { Mean: } 5.09 \\
\text { SD: } 1.36\end{array}$ & $\begin{array}{l}\text { Mean: } 5.05 \\
\text { SD: } 1.49\end{array}$ \\
\hline & PBC5 & $\begin{array}{l}\text { I have the } \\
\text { opportunities } \\
\text { to purchase } \\
\text { sustainably } \\
\text { grown vegeta- } \\
\text { bles }\end{array}$ & $\begin{array}{l}\text { Mean: } 5.23 \\
\text { SD: } 1.36\end{array}$ & $\begin{array}{l}\text { Mean: } 5.27 \\
\text { SD: } 1.40\end{array}$ & $\begin{array}{l}\text { Mean: } 5.18 \\
\text { SD: } 1.30\end{array}$ \\
\hline & PBC6** & $\begin{array}{l}\text { I have the } \\
\text { resources } \\
\text { to purchase } \\
\text { sustainably } \\
\text { grown vegeta- } \\
\text { bles }\end{array}$ & $\begin{array}{l}\text { Mean: } 4.56 \\
\text { SD: } 1.58\end{array}$ & $\begin{array}{l}\text { Mean: } 4.70 \\
\text { SD: } 1.64\end{array}$ & $\begin{array}{l}\text { Mean: } 4.35 \\
\text { SD: } 1.47\end{array}$ \\
\hline
\end{tabular}




\begin{tabular}{|c|c|c|c|c|c|}
\hline \multirow[t]{2}{*}{ Factor } & \multirow[t]{2}{*}{ Item Name } & \multirow[t]{2}{*}{ Item } & \multicolumn{3}{|c|}{ Descriptive statistics } \\
\hline & & & $\begin{array}{l}\text { Unsegmented } \\
\text { sample }\end{array}$ & $\begin{array}{l}\text { Full-time } \\
\text { employed }\end{array}$ & $\begin{array}{l}\text { Not (yet) } \\
\text { full-time } \\
\text { employed }\end{array}$ \\
\hline \multirow[t]{3}{*}{ Intention } & INT1 & $\begin{array}{l}\text { I will purchase } \\
\text { sustain- } \\
\text { ably grown } \\
\text { vegetables for } \\
\text { personal use }\end{array}$ & $\begin{array}{l}\text { Mean: } 4.97 \\
\text { SD: } 1.33\end{array}$ & $\begin{array}{l}\text { Mean: } 4.98 \\
\text { SD: } 1.37\end{array}$ & $\begin{array}{l}\text { Mean: } 4.97 \\
\text { SD: } 1.26\end{array}$ \\
\hline & INT2 & $\begin{array}{l}\text { I am willing } \\
\text { to purchase } \\
\text { sustain- } \\
\text { ably grown } \\
\text { vegetables for } \\
\text { personal use }\end{array}$ & $\begin{array}{l}\text { Mean: } 5.13 \\
\text { SD: } 1.34\end{array}$ & $\begin{array}{l}\text { Mean: } 5.12 \\
\text { SD: } 1.33\end{array}$ & $\begin{array}{l}\text { Mean: } 5.14 \\
\text { SD: } 1.38\end{array}$ \\
\hline & INT3 & $\begin{array}{l}\text { I will make an } \\
\text { effort to pur- } \\
\text { chase sustain- } \\
\text { ably grown } \\
\text { vegetables }\end{array}$ & $\begin{array}{l}\text { Mean: } 5.06 \\
\text { SD: } 1.31\end{array}$ & $\begin{array}{l}\text { Mean: } 5.00 \\
\text { SD: } 1.36\end{array}$ & $\begin{array}{l}\text { Mean: } 5.15 \\
\text { SD: } 1.23\end{array}$ \\
\hline
\end{tabular}

\footnotetext{
*Eliminated during the model evaluation process for the model concerning not (yet) full-time employed respondents

**Eliminated during the model evaluation process in both models

${ }^{\mathrm{R}}$ Reverse coded
}

Acknowledgements We thank the three anonymous reviewers for their helpful comments to strengthen the contributions made in this study.

Funding Open Access funding enabled and organized by Projekt DEAL.

\section{Declarations}

Conflict of interest The authors whose names are listed above certify that they have NO affiliations with or involvement in any organization or entity with any financial interest (such as honoraria; educational grants; participation in speakers' bureaus; membership, employment, consultancies, stock ownership, or other equity interest; and expert testimony or patent-licensing arrangements), or non-financial interest (such as personal or professional relationships, affiliations, knowledge or beliefs) in the subject matter or materials discussed in this manuscript.

Open Access This article is licensed under a Creative Commons Attribution 4.0 International License, which permits use, sharing, adaptation, distribution and reproduction in any medium or format, as long as you give appropriate credit to the original author(s) and the source, provide a link to the Creative Commons licence, and indicate if changes were made. The images or other third party material in this article are included in the article's Creative Commons licence, unless indicated otherwise in a credit line to the material. If material is not included in the article's Creative Commons licence and your intended use is not permitted by statutory regulation or exceeds the permitted use, you will need to obtain permission directly from the copyright holder. To view a copy of this licence, visit http://creativecommons.org/licen ses/by/4.0/. 


\section{References}

Ajzen I (1985) From intentions to actions: a theory of planned behaviour. In: Kuhl J, Beckmann J (eds) Action control: from cognition to behaviour. Springer, Heidelberg

Ajzen I (1991) The theory of planned behavior. Organ Behav Hum Decis Process 50:179-211

Ajzen I (2002) Residual effects of past on later behavior: habituation and reasoned action perspectives. Pers Soc Psychol Rev 6:107-122

Ajzen I, Fishbein M (1980) Understanding attitudes and predicting social behavior. Prentice-Hall, Englewood Cliffs

Asselmann E, Specht J (2021) Personality maturation and personality relaxation: differences of the Big Five personality traits in the years around the beginning and ending of working life. J Pers. https:// doi.org/10.1111/jopy.12640

Beatty SE, Kahle LR, Homer P, Misra S (1985) Alternative measurement approaches to consumer values: the list of values and the Rokeach value survey. Psychol Mark 2:181-200

Bollen KA (1989) Structural equations with latent variables. Wiley, New York

Brach S, Walsh G, Shaw D (2018) Sustainable consumption and third-party certification labels: consumers' perceptions and reactions. Eur Manag J 36:254-265

Brix-Asala C, Hahn R, Seuring S (2016) Reverse logistics and informal valorisation at the Base of the Pyramid: a case study on sustainability synergies and trade-offs. Eur Manag J 34:414-423

Caplan E (2005) Brand loyalty. Dealerscope May 20:60

Chan RYK, Lau LBY (2002) Explaining green purchasing behavior. J Int Consum Mark 14(2-3):9-40

Chen P-J, Choi Y (2008) Generational differences in work values: a study of hospitality management. Int J Contemp Manag 20:595-615

Clawson CJ, Vinson DE (1978) Human values: a historical and interdisciplinary analysis. Adv Consum Res 5:396-402

De Groot JIM, Steg L (2007) Value orientations and environmental beliefs in five countries. J Cross Cult Psychol 38:318-332

De Groot JIM, Steg L (2008) Value orientations to explain beliefs related to environmental significant behaviour. Environ Behav 40:330-354

Donnelly C, Scaff R (2013) Who are the millennial shoppers? And what do they really want? Outlook. J High Perform Bus 2:1-7

Edelman / StrategyOne (2010) The 8095 Exchange: Millennials, their actions surrounding brands, and the dynamics of reverberation. Retrieved from: www.slideshare.net/EdelmanDigital/8095-whitepaper. Accessed: 08 Nov 2021

Ellen PS, Wiener JL, Cobb-Walgren C (1991) The role of perceived consumer effectiveness in motivating environmentally conscious behaviors. J Public Policy Mark 10:102-117

Falke A, Schröder N, Endres H (2020) A first fit index on estimation accuracy in structural equation models. J Bus Econ 90:277-302

Furlow N (2011) Find us on Facebook: how cause marketing has embraced social media. J Mark Develop Compet 5:61-64

Grunert SC, Scherlorn G (1990) Consumer values in West Germany underlying dimensions and crosscultural comparison with North America. J Bus Res 20:97-107

Gurău C (2012) A life-stage analysis of consumer loyalty profile: comparing Generation X and Millennial consumers. J Consum Mark 29:103-113

Gurel-Atay E, Xie G-X, Chen J, Kahle LR (2010) Changes in social values in the United States: 19762007. J Advert Res 50:57-67

Gurel-Atay E, Kahle LR, Lengler JB, Kim C-H (2019) A comparing and contrasting of the list of values and the Schwartz value scale. In: Kahle LR (ed) Consumer social values. Routledge Taylor \& Francis Group, New York

Heo J, Muralidharan S (2019) What triggers young Millennials to purchase eco-friendly products?: the interrelationships among knowledge, perceived consumer effectiveness, and environmental concern. J Mark Commun 25(4):421-437. https://doi.org/10.1080/13527266.2017.1303623

Homer PM, Kahle LR (1988) A structural equation test of the value-attitude-behavior hierarchy. J Pers Soc Psychol 54:638-646

Howe N, Strauss W (2000) Millennials rising: the next great generations. Vintage Books, New York

Hwang J, Griffiths MA (2017) Share more, drive less: Millennials value perception and behavioral intent in using collaborative consumption services. J Consum Mark 34:132-146 
Jaiswal D, Kant R (2018) Green purchasing behaviour: a conceptual framework and empirical investigation of Indian consumers. J Retail Consum Serv 41:60-69

Kahle LR (1983) Social values and social change; adaption to life in America. Praeger, New York

Kahle LR (1984) The values of Americans: implications for consumer adaptation. In: Pitts RE Jr, Woodside AG (eds) Personal values and consumer psychology. Mass: Lexington Books, Lexington

Kahle LR, Kennedy P (1988) Using the list of values (LOV) to understand consumers. J Serv Mark 2:49-56

Kahle LR, Poulos B, Sukhdial A (1988) Changes in social values in the United States during the past decade. J Advert Res 28:35-41

Kamakura WA, Novak TP (1992) Value-system segmentation: exploring the meaning of LOV. J Consum Res 19:119-132

Kang J, Liu C, Kim S-H (2013) Environmentally sustainable textile and apparel consumption: the role of consumer knowledge, perceived consumer effectiveness and perceived personal relevance. Int $\mathrm{J}$ Consum Stud 37:442-452

Kim YJ, Njite D, Hancer M (2013) Anticipated emotion in consumers' intentions to select eco-friendly restaurants: augmenting the theory of planned behaviour. Int J Hosp Manag 34:255-262

Littrell M, Ma YJ, Halepete J (2005) Generation X, baby boomers, and swing: marketing fair trade apparel. J Fash Mark Manag 9:407-419

Ma YJ, Littrell MA, Niehm L (2012) Young female consumers' intentions toward fair trade consumption. Int J Retail Distrib Manag 40:41-63

Madrigal R, Kahle LR (1994) Predicting vacation activity preferences on the basis of value-system segmentation. J Travel Res 32:22-28

Maslow AH (1954) Motivation and psychology. Harper, New York

McCarty JA, Shrum LJ (1994) The recycling of solid wastes: personal values, value orientations, and attitudes about recycling as antecedents of recycling behaviour. J Bus Res 30:53-62

Nacu-Schmidt A, Katzung J, Boykoff M (2020) Media and climate change observatory special issue 2019: A review of media coverage of climate change and global warming in 2019. Retrieved from https://scholar.colorado.edu/concern/articles/qn59q4937. Accessed 08 Nov 2021

Naderi I, van Steenburg E (2018) Me first, then the environment: young Millennials as green consumers. YC 19:280-295

Nordlund AM, Garvill J (2002) Value structures behind proenvironmental behavior. Environ Behav 34:740-756

Padel S, Foster C (2005) Exploring the gap between attitudes and behaviour: understanding why consumers buy or do not buy organic food. Br Food J 107:606-625

Paetz F (2021) Personality traits as drivers of social preferences: a mixed logit model application. J Bus Econ 91:303-332

Parment A (2012) Generation Y in consumer and labour markets. Routledge, New York

Parment A (2013) Generation Y vs. Baby Boomers: shopping behavior, buyer involvement and implications for retailing. J Retail Consum Serv 20:189-199

Phillips C (2007) Millennials: clued in or clueless? Advertising Age November: 12-13

Ramzan S, Lie CG, Xu Y, Munir H, Gupte B (2020) The adoption of online e-waste collection platform to improve environmental sustainability: an empirical study of Chinese millennials. MEQ 32:193-209

Rex J, Lobo A, Leckie C (2015) Evaluating the drivers of sustainable behavioural intention: an application and extension of the theory of planned behaviour. J Nonprofit Public Sect Mark 27:263-284

Roberts JA (1996) Green consumers in the 1990s: Profile and implications for advertising. J Bus Res 36:217-231

Rokeach M (1973) Beliefs, attitudes and values: a theory of organization and change. Jossey-Bass, San Francisco

Schultz PW, Zelezny LC (1999) Values as predictors of environmental attitudes: evidence for consistency across 14 countries. J Environ Psychol 19:255-265

Schwartz SH (1992) Universals in the content and structure of values: theoretical advances and empirical tests in 20 countries. Adv Exp Soc Psychol 25:1-65

Schwartz SH (2003) A proposal for measuring value orientations across nations. In Questionnaire Development Package of the European Social Survey: 259-319

Shaw D, Shiu E (2003) Ethics in consumer choice: a multivariate modelling approach. Eur J Mark 37:1485-1498

Shim S, Eastlick MA (1998) The hierarchical influence of personal values on mall shopping attitude and behaviour. J Retail 74:139-160 
Smith KT (2012) Longitudinal study of digital marketing strategies targeting Millennials. J Consum Mark 29:86-92

Stern PC, Dietz T, Kalof L (1993) Value orientations, gender, and environmental concern. Environ Behav 25:322-348

Stern PC, Dietz T, Kalof L, Guagnano GA (1995) Values, beliefs, and proenvironmental action: attitude formation toward emergent attitude objects. J Appl Soc Psychol 25:1611-1636

Twenge JM, Foster JD (2010) Birth cohort increases in narcissistic personality traits among American college students, 1982-2009. Social Psychol Pers Sci 1:99-106

Valentine DB, Powers TL (2013) Generation Y values and lifestyle segments. J Consum Mark 30:597-606

Vermeir I, Verbeke W (2008) Sustainable food consumption among young adults in Belgium: theory of planned behavior and the role of confidence and values. Ecol Econ 64:542-553

VuMa (2018) Arbeitsgemeinschaft Verbrauchs- und Medienanalyse. Millenials in Deutschland nach Berufstätigkeit im Vergleich mit der Bevölkerung im Jahr 2018 [Millenials in Germany split by occupation in comparison to the population in 2018]. Retrieved from https://de.statista.com/stati stik/daten/studie/713008/umfrage/umfrage-in-deutschland-zurberufstaetigkeit-der-millennials/. Accessed 08 Nov 2021 (in German)

Wan C, Cheung R, Shen GQ (2012) Recycling attitude and behavior in university campus: a case study in Hong Kong. Facilities 30:630-646

World Commission on Environment and Development (WCED) (1987) Our common future. Oxford University Press, Oxford

Yadav R, Pathak GS (2017) Determinants of consumer's green purchase behavior in a developing nation: applying and extending the theory of planned behavior. Ecol Econ 134:114-122

Yoon C (2009) The effects of national culture values on consumer acceptance of e-commerce: online shoppers in China. Inform Manag 46:294-301

Publisher's Note Springer Nature remains neutral with regard to jurisdictional claims in published maps and institutional affiliations.

\section{Authors and Affiliations}

\section{Andreas Falke ${ }^{1} \cdot$ Nadine Schröder $^{2} \cdot$ Claudia Hofmann ${ }^{3}$}

Nadine Schröder

nadine.schroeder@wu.ac.at

Claudia Hofmann

claudia.hofmann@mail.de

1 University of Regensburg, Universitätsstr. 31, 93040 Regensburg, Germany

2 WU Wien, Vienna University of Economics and Business, Welthandelsplatz 1, 1020 Vienna, Austria

3 R-Tech GmbH, Franz-Mayer-Str. 1, 93053 Regensburg, Germany 